\title{
Uticaj prava intelektualnog vlasništva na nacionalne sisteme nauka
}

\author{
Joseph Straus* \\ "Nauka, više od bilo čega drugog među institucijama \\ čovječanstva, raste poput korova iz godine u godinu. Umjetnost \\ je podložna hirovima mode, religija je okrenuta ka unutra \\ i vođena tako da održi samu sebe, a pravo se kreće između \\ oslobađanja i porobljavanja." \\ K. B. Mullis (dobitnik Nobelove nagrade za hemiju 1993)
}

Sažetak: Nakon izlaganja o postupcima razvoja i korištenja vakcina protiv COVID-19 u 2020. godini, kao primjera uspješne saradnje između akademske zajednice, industrije i vlada $\mathrm{u}$ podršci istraživanju i pretvaranju njegovih rezultata u inovacije potpomognute patentima, ovaj rad se okreće nacionalnim naučnim sistemima. Prvo se bavi pionirskom ulogom izveštaja "Nauka, beskrajna granica" ("Science the Endless Frontier”) iz 1945. godine, koji predstavlja Magna cartu američke nauke i njene politike patenata. Pomenuti su i kasniji razvoji u SAD-u koji otkrivaju postupni zaokret od poticanja prijenosa znanja i tehnologije sa institucija koje finansira država na industriju, dopuštajući to samo u obliku neekskluzivnih licenci, do nametanja obaveze komercijalizacije rezultata istraživanja javnom istraživačkom sektoru, dopuštajući ekskluzivne licence i prijenos prava intelektualnog vlasništva privatnim kompanijama, a sve uz prepoznavanje i očuvanje akademske slobode i istraživanja. Dalje, rad tematizira razvoj na razvoj događaja u zemljama u kojima su zakonodavci generalno slijedili američki model. Naposlijetku, ovaj prilog govori o sistemu prava intelektualnog vlasništva u svjetlu specifičnih potreba akademskih istraživača.

Ključne riječi: relacije Univerzitet-industrija-vlada, prava intelektualnog vlasništva, nacionalni sistemi nauke

\section{Uvod}

Rijetko su, ako ikada u doba mira, događaji poput onih koji su okarakterizirali 2020. godinu, na impresivniji način pokazali značaj takozvanog Triple Helix savezništva za dobrobit svjetskog društva. Pojam saveza "trostrukog heliksa"

\footnotetext{
${ }^{*}$ Prof. dr. jur. dres. jur. h.c., professor prava, Univerzitet u Minhenu i Univerzitet u Ljubljani, direktor emeritus na Max Planck institutu za inovacije i konkurenciju u Minhenu. Inostrani član Akademije nauka i umjetnosti Bosne i Hercegovine. E-mail: j.straus@ip.mpg.de
} 
označava "spiralni model inovacija u smislu odnosa na relaciji univerzitetiindustrije-vlade [potreban] da bi se uhvatio razvoj višestrukih veza u različitim fazama kapitalizacije znanja". ${ }^{1}$ Samo zahvaljujući uspješnoj i intenzivnoj interakciji između univerziteta, industrija i vlada bilo je moguće, po prvi put u historiji, razviti i staviti na tržište nove vakcine za borbu protiv pandemije SARS 2 COVID-19. Naučne i tehnološke osnove za cjepiva BioNTechPfizer, Moderna i Oxford-AstraZeneca, koji su kao prvi dobili odobrenje i stupili na tržište, potječu iz kasnih 1980-ih i 1990-ih.

Prvo je uska međunarodna saradnja između javno finansiranih istraživačkih institucija i biotehnoloških kompanija, oslanjajući se na patente koji štite njihove osnovne istraživačke izume, ${ }^{2}$ stvorila prve terapije zasnovane na rekombinantnoj DNK tehnologiji, poput humanog inzulina, eritropoetina (EPO), faktora koji stimulišu granulocitne kolonije (GCSF) i drugih. Zatim, desetak godina intenzivnih zajedničkih napora u okviru Projekta humanog genoma (HGP), međunarodno podržanog javnog projekta (paralelnog s Celera Genomics privatnim projektom), 2001. godine kulminiralo je dešifriranjem čitavog ljudskog genoma. ${ }^{3}$ Dok su istraživači Oxford-AstraZeneca u svoju vakcinu uveli dvolančanu DNK S proteina Coronavirusa koristeći drugi virus (adenovirus) kao vektor, ${ }^{4}$ što je dakle pristup razvijen 1990-ih, BioNTech i Moderna vakcine nose instrukcije za izgradnju S proteina u jednolančanoj RNK.

Da bi na kraju dobili BioNTech-Pfizer i Moderna vakcine koje koriste RNA nosilac kao "vektor", bila je potrebna promjena paradigme, potaknuta istraživačkim radom na mRNA s obje strane Atlantika. Međutim, dok su Katalin Karikó i Drew Weissman, istraživači koji su radili na mRNA na Univerzitetu

\footnotetext{
${ }^{1}$ Leydesdorff \& Etzkowitz, Emergence of a Triple Helix of University-Industry-Government Relations, 1996:279-286, citirano iz Leydesdorff \& Etzkowitz, The Future Location of Research: A Triple Helix of University-Industry-Government Relations II, 1996: 20-25. Za detaljnu raspravu Triple Helix-a kao modela za inovacijske studije, usp. Etzkowitz \& Leydesdorff, Universities and the Global Knowledge Economy: A Triple Helix of University-Industry-Government Relations, 1997:1-8 i Viale \& Etzkowitz, Third Academic Revolution: Polyvalent Knowledge; The "DNA" of the Triple Helix, 2005, dostupno na

https://www.researchgate.net/publication/242406526_Third_academic_revolution_polyvalent_knowledge_theDNA_of_the_triple_helix (posljednji pristup 9. februara 2021). i Leydesdorff, The Triple Helix: An Evolutionary Model of Innovations, 2000:243-255.

${ }^{2}$ Usp. npr. Straus, Intellectual Property Rights and Bioeconomy, 2017:576-590 (str. 580-582).

${ }^{3}$ Fraser, Editorial: A Genome to Celebrate, 2021:545; Jones \& Cook-Deegan, Complicated Legacies: The Human Genome at 20, 2021:564-569.

${ }^{4}$ Usp. Corum \& Zimmer, How the Oxford-AstraZeneca Vaccine Works, The New York Times of February 8, 2021 (https://www.nytimes.com/interactive/2020/health/oxford-astrazeneca-covid-19-vaccine.html (posljednji pristup 9. februara 2021)).
} 
u Pennsylvaniji tokom 1990-ih, hvaljeni kao ključni istraživači za razvoj terapija zasnovanih na mRNA ${ }^{5}$ pošto su 2005. objavili svoj rad, ${ }^{6}$ ime Ingmara Hoerra, jednog od ranih pionira Evrope u istraživanju mRNA, nigdje se ne spominje. Ingmar Hoerr koji je započeo svoj doktorski rad sredinom 1990ih bio je uvjeren da RNA može biti platforma za razvoj mnoštva terapija, od profilaktičkih vakcina do imunoterapija. Za razliku od Karikó i Weissmana koji su modificiranim verzijama, nazvanim pseudouridin i 5-metiluridin, tj. nukleozidima, smanjili antivirusni odgovor mRNA uridina, i dobili patent za njihovu upotrebu 2012. godine, ${ }^{7}$ Hoerr je stabilizirao mRNA modifikacijom sekvence. Od 1999. godine, Hoerr je podnio brojne prijave za patente, npr. 5. juna 2001., odnosno prije 20 godina, za "Farmaceutski sastav koji sadrži stabiliziranu mRNA optimiziranu za prevođenje u svojim regijama kodiranja". ${ }^{8}$ Hoerr je svoja otkrića objavio 2000. godine u svojoj doktorskoj tezi pod nazivom "RNK vakcina za indukciju specifičnih citotoksičnih T-limfocita (CTL) i antitijela" i zajedno sa svojom grupom u časopisu European Journal of Immunology. ${ }^{10}$ Njegovo otkriće olakšalo je upotrebu ribonukleinske kiseline za razvoj vakcina i imunoterapija. RNK vakcine mogu se proizvoditi u velikim količinama i mogu postići isti napredak kao DNK vakcine, a nemaju potencijalno štetan učinak integracije DNK u genom. Međutim, Ingmar Hoerr nije samo "ključni rani pionir mRNA" koji je riješio problem stabiliziranja mRNA promjenom paradigme. ${ }^{11}$ Dr. Hoerr također predstavlja poduzetnički duh i izvanrednu neposustajuću energiju potrebnu da se važno osnovno istraživačko otkriće pretvori u komercijalni proizvod koji koristi društvu, tj. vakcinu. Ingmar Hoerr osnovao je 2000. uspješnu biotehnološku kompaniju

\footnotetext{
${ }^{5}$ Usp. Keener, Just the Messenger: A New Class of Therapeutic Instruct the body to make its own drugs, 2018:1294-1300; Gaveria \& Kilic, A Network Analysis of COVID-19 mRNA Vaccine Patents, 2021:546-549; Fauci, The Story Behind COVID-19 Vaccines, 2021; Kolata, Kati Kariko Helped Shield the World From the Coronavirus, 2021.

${ }^{6}$ Karikó \& Buckstein \& Ni \& Weissman, Suppression of RNA Recognition by Toll-like Receptor: The Impact of Nucleoside Modification and the Evolution Origin of RNA, 2005:165175, sa referencama na neke od njihovih ranijih publikacija.

${ }^{7}$ Prema Keener-u, supra br. 6, str. 1299.

${ }^{8}$ US Patent 10188748 B2 (A1) od 29. januara 2019, prioritetna prijava 5. juna 2001. (prijava objavljena 12. decembra 2002).

${ }^{9}$ Usp. Wikipedia pod Ingmar Hoerr.

${ }^{10}$ Usp. Hoerr \& Obst \& Rammensee \& Jung, In Vivo Application of RNA Leads to Induction of Specific Cytotoxic T-Lymphocytes and Antibodies, 2000:1-7.

${ }^{11}$ Kuhn naglašava, "Naučna zajednica izuzetno je efikasan instrument za maksimiziranje broja i preciznosti problema riješenih promjenom paradigme.” (Kuhn, The Structure of Scientific Revolutions, 1970 (str. 169).
} 
CureVac sa sjedištem u Tübingenu, koja sada u saradnji s GlaxoSmithKline radi na vakcini efikasnoj i protiv brazilskih, britanskih i južnoafričkih mutacija COVID-19. U članku objavljenom 2017. godine, Hoerr je detaljno opisao ne samo izazovan temelj kompanije, borbu za nagovaranje i okupljanje javnih i privatnih investitora da osiguraju potrebna sredstva itd. već je naglasio i da su "valjani pretklinički podaci i idealno široki patenti" bili presudni za uspjeh kompanije. ${ }^{12}$ Teško je razumjeti da radovi koji izvještavaju o CureVac-ovim programima za mRNA vakcine protiv gripe i malarije, podržanim od strane Bill \& Melinda Gates fondacije, ili o prvim kliničkim ispitivanjima CureVac mRNA vakcine protiv raka prostate provedenim već 2008 . godine, ${ }^{13}$ niti ne spominju ime Ingmara Hoerra, osnivača CureVac-a, niti njegov ključni rad objavljen 2000. godine!

Kada je u pitanju razvoj i odobravanje za stavljanje u promet nove vakcine, što zahtijeva desetine hiljada kliničkih testova i košta stotine miliona ili više eura ili dolara, univerziteti, javne istraživačke institucije, pa čak i uspješne biotehnološke start-up kompanije trebaju jake privatne i javne saveznike. Finansijski rizici su takve magnitude da čak i velike farmaceutske kompanije u pravilu zaziru od takvih pothvata ako vlada ne signalizira svoju spremnost da finansijski podrži projekt. U slučaju razvoja vakcina protiv koronavirusa, čak je i farmaceutski gigant poput američke kompanije Merck\&Co., unatoč već provedenom ulaganju, odustao od svojih napora zbog neuspjeha koje je doživio. Međunarodna federacija proizvođača farmaceutskih proizvoda (IFPMA) procjenjuje da će izdaci proizvođača lijekova, kada je u pitanju razvoj vakcina protiv koronavirusa i njihova proizvodnja, iz privatnih fondova do kraja 2021. godine iznositi više od 10 milijardi američkih dolara. Međutim, za razvoj vakcina protiv koronavirusa rano javno finansiranje također je bilo od ključne važnosti. Bez tog finansiranja kompanije nikada ne bi pokrenule tako široku inicijativu. Daleko najvažnije bilo je finansiranje koje je osigurao program vlade SAD-a, “Operacija Warp Speed”, koji je generirao više od 12 milijardi američkih dolara. EU je bila mnogo skromnija. U tu će svrhu potrošiti ne više od nekoliko stotina miliona eura. Presudni za nevjerovatnu brzinu razvoja vakcina protiv koronavirusa nisu bili samo angažman najboljih istraživača i finansijska podrška vlada, već i mogućnost globalnog tržišta bez presedana. Prodaja predviđena za 2021. godinu je impresivna: Pfizer (

\footnotetext{
${ }^{12}$ Usp. Hoerr, A Successful Founder off the Beaten Path, 2017:900-903 (str. 902, dodan naglasak).

${ }^{13}$ Usp. npr. Keener, supra br. 6, str. 1298, izvještaj o CureVacu koji u potpunosti ignoriše Hoerra.
} 
15 milijardi američkih dolara), Moderna ( 12 milijardi američkih dolara), BioNTech ( $\sim 8$ milijardi američkih dolara), CureVac $(\sim 5$ milijardi američkih dolara) i AstraZeneca ( 4 milijarde američkih dolara) ${ }^{14}$

Međutim, izuzetno cijenjeni i pozdravljeni uspjeh Triple Helix saveza, koji je isporučio nove vakcine za borbu protiv pandemije koronavirusa za nevjerovatnih godinu dana, već je zamagljen. Razlog tome je što proizvodni kapaciteti znatno zaostaju za hitnom potražnjom, ogromni ukupni troškovi vakcinacije cijele populacije koji su nedostižni mnogim, ako ne i većini zemalja, i perspektiva dobiti koju proizvođači vakcina, korisnici javnih finansiranja vrijednih više milijardi, mogu očekivati zahvaljujući njihovim patentima. Ne iznenađuje da su uslijedili pozivi za obavezno udruživanje patenata, prisilne licence itd., kako bi se prevazišli problemi, kao i prijedlozi za rješavanje problema slabljenjem zaštite patenata. ${ }^{15}$ Iznenađujuća je pak bila odluka američkog predsjednika Joea Bidena od 5. maja 2021. godine da podrži privremeno odricanje patenata za vakcine protiv Covid- $19,{ }^{16}$ što je izazvalo ne samo veliku zabrinutost farmaceutske industrije, već nije smatrano niti primjerenim niti produktivnim od strane evropskih lidera poput njemačke kancelarke Angele Merkel i francuskog predsjednika Emmanuela Macrona. ${ }^{17}$

\section{Nacionalni sistemi nauka}

(a) SAD - Pionir

2020. godine SAD su proslavile 75. godišnjicu onoga što se smatra "Magna cartom američke nauke", ${ }^{18}$ izvještaj Science, the Endless Frontier, koji je Vannevar Bush, direktor Ureda za naučno istraživanje i razvoj, predao predsjedniku Harryju Trumanu 25. jula 1945. (u daljem tekstu "Izvještaj”). ${ }^{19}$ Ovaj

\footnotetext{
${ }^{14}$ Usp. Benz \& Feldges, Ein Turbo für die Impfstoff-Hersteller: Lässt sich die Produktion von Corona-Vakzinen Beschleunigen?, 2021. (https://www.nzz.ch/wirtschaft/corona-impfungmoeglichkeiten-zur-beschleunigung-der-produktion-ld.1599788 (posljednji pristup 8. februara 2021).

${ }^{15}$ Usp. npr. Abbott \& Reichman, Facilitating Access to Cross-Border Supplies of Patented Pharmaceuticals: The Case of the COVID-19 Pandemic, 2020:535-561.

${ }^{16}$ Usp. npr. Asgari \& Mancini \& Kuchler, Pharma Industry Fears Biden's Patent Decision Sets Dangerous Precedent, Financial Times, 07. maja 2021., str. 3; Stacey \& Williams, Biden's Diplomatic Victory Blunts Pharma Lobby, Financial Times od 10. maja 2021., str. 4. ${ }^{17}$ Usp. npr. Peel, EU Leaders. Confront US over Vaccine Patent Waiver Demands, Financial Times od 8. maja 2021, str. 2.

${ }^{18}$ Thorp, Editorial: Science has always been Political, 2020:227.

${ }^{19} \mathrm{https}$ ://www.nsf.gov/od/lpa/nsf50/vbush1945.htm (posljednji pristup 3. februara 2021).
} 
izvještaj rezultat je zahtjeva predsjednika Franklina D. Roosevelta iz 1944. koji je tražio odgovore / ideje na četiri pitanja. Sva su bila fokusirana na to kako se najbolje rezultati istraživačkog rada koji je Bushov ured tako uspješno proveo "u najvećoj tajnosti, i bez ikakvog javnog priznanja; ali njegovi opipljivi rezultati mogu se naći u priopćenjima koja su dolazila s ratišta širom svijeta", mogu profitabilno koristiti u doba mira. Dakle, "za poboljšanje nacionalnog zdravlja, stvaranje novih preduzeća koja donose nova radna mjesta i poboljšanje nacionalnog životnog standarda."20

Kako podvlači glavni urednik revije Science, Holden Thorp, Bushov Izvještaj izložio je obrazloženje i strukturu sistema za finansiranje nauke u SAD-u. ${ }^{21}$ Što se tiče obrazloženja, Izvještaj je naglasio da: "nauka može biti djelotvorna u nacionalnoj dobrobiti samo kao član tima, bilo to u uslovima mira ili rata. Ali, bez napretka nauke, niti jedno postignuće u drugim smjerovima ne može osigurati naše zdravlje, prosperitet i sigurnost kao nacije u modernom svijetu." 22 Dakle, vlada bi trebala prihvatiti nove odgovornosti za promociju protoka novih naučnih saznanja i razvoj naučnog talenta omladine. ${ }^{23}$ Izvještaj preporučuje da se uspostavi nova agencija za te svrhe. Ta agencija "trebala bi prepoznati da se sloboda istraživanja mora očuvati i trebala bi prepustiti internu kontrolu politike, osoblja i metoda i opsega istraživanja institucijama u kojima se isto provodi. Trebala bi biti u potpunosti odgovorna predsjedniku i preko njega Kongresu za svoj program." ${ }^{24}$ Kao rezultat ovog izvještaja, predsjednik Harry Truman 10. maja 1950. godine osnovao je Nacionalnu fondaciju za nauku, osmišljenu na principu da naučnici sami trebaju odrediti tok temeljnih istraživanja. ${ }^{25}$

U kontekstu ovog rada i s obzirom na tekuće rasprave o uticaju prava intelektualnog vlasništva, posebno patenata, na naučni napredak i prevođenje javno finansiranih rezultata istraživanja u inovativne proizvode i procese, sljedeće izjave iz izvještaja "Nauka, beskrajna granica" čine se od trajne važnosti.

"Najvažniji načini na koje vlada može promovirati industrijsko istraživanje su povećavanje protoka novih naučnih saznanja kroz podršku osnovnim

\footnotetext{
${ }^{20}$ Predsjedničko pismo od 17. novembra 1944. (ibid. str. 3, 4).

${ }^{21}$ Thorp, supra br. 18.

22 The Report, str. 5.

${ }^{23}$ Ibid str. 7.

${ }^{24}$ Ibid str. 8.

${ }^{25}$ Usp. Gibson, Overseeing Innovation: 75 Years after Vannevar Bush's Impactful Report, Debate Continuous About Directing Science, 2020:258-259 (str. 259).
} 
istraživanjima i pomoć u razvoju naučnih talenata. Uz to, vlada bi trebala pružiti odgovarajuće poticaje industriji za provođenje istraživanja, (a) razjašnjavanjem sadašnjih nesigurnosti u Zakonu o unutrašnjim prihodima u pogledu odbitka troškova za istraživanje i razvoj kao tekućih troškova neto dobiti, i (b) jačanje patentnog sistema kako bi se eliminisale nesigurnosti koje sada opterećuju male industrije i kako bi se spriječile zloupotrebe koje odražavaju diskreditaciju sistema koji je u osnovi zdrav. Pored toga, trebalo bi pronaći načine kako da prednosti osnovnog istraživanja dođu do industrija koje trenutno ne koriste nova naučna saznanja". ${ }^{26}$

"V. Politika patenata. - Uspjeh Nacionalne istraživačke fondacije u promociji naučnog istraživanja u ovoj zemlji ovisit će u velikoj mjeri o saradnji organizacija izvan vlade. U sklapanju ugovora sa tim organizacijama ili davanjem bespovratnih sredstava za njih, Fondacija bi trebala adekvatno zaštititi javni interes i istovremeno ostaviti saradničkoj organizaciji dovoljnu slobodu i podsticaj za obavljanje naučnih istraživanja. Javni interes obično će biti adekvatno zaštićen ako vlada dobije licencu bez naknade za vladine svrhe prema bilo kojim patentima koji proizilaze iz rada koji finansira Fondacija. Istraživačka institucija ne bi trebala biti dužna patentirati otkrića nastala kao rezultat podrške Fondacije. Svakako ne bi trebao postojati apsolutni zahtjev da se sva prava na takva otkrića dodijele Vladi, već to treba biti prepušteno diskreciji direktora i zainteresiranog odjeljenja da li u posebnim slučajevima javni interes zahtijeva takvu dodjelu. Zakonodavstvo po ovom pitanju trebalo bi članovima Fondacije prepustiti diskreciju u pogledu njihove politike patenata kako bi se aranžmani patenata mogli prilagoditi prema okolnostima i javnom interesu." ${ }^{27}$

Kao rezultat politike patenata integrirane u izvještaj "Nauka, beskrajna granica”, američki univerziteti i institucije koje se finansiraju iz javnog sektora aktivno su se angažirali u patentima. Dobili su brojne patente, međutim, vrlo rijetko komercijalno iskorištene. Budući da patenti izdani na javno finansiranim rezultatima istraživanja nisu mogli biti niti ekskluzivno licencirani niti transferirani privatnim preduzećima, nije došlo do njihovog prevođenja u inovativne proizvode i procese. Krajem 1970-ih, od 25.000 do 30.000 patenata u vlasništvu vlade, manje od $5 \%$ njih je licencirano. ${ }^{28}$ Da bi prevazišle ovu ekonomski nepovoljnu situaciju, SAD su 1980-ih donijele nekoliko zakona čiji je cilj bio poticanje prenosa tehnologija koje su rezultirale iz federalno finansiranih istraživanja provođenih na univerzitetima i akademskim

\footnotetext{
${ }^{26} \mathrm{Ibid}$, Sažetak (str. 6).

${ }^{27}$ Ibid str. 30.

${ }^{28}$ Usp. Straus, supra br. 2 (str. 581).
} 
istraživačkim institucijama. Godine 1980. Bayh-Doleov zakon ${ }^{29}$ uveo je mogućnost da privatne stranke zadrže patentna prava putem "title in contractor" politike, tj. mogućnosti za mala preduzeća i neprofitne organizacije, uključujući univerzitete, da zadrže prava intelektualnog vlasništva nad rezultatima istraživanja koja se finansiraju iz federalnih izvora. Također 1980. godine, Stevenson-Wydlerov zakon ${ }^{30}$ zahtijevao je od saveznih agencija koje upravljaju istraživanjem da uspostave Ured za istraživanje i tehnološke primjene (ORTA) u svim laboratorijama kojima upravlja država ili kooperanti sa godišnjim budžetom većim od 20 miliona američkih dolara. Godine 1986. Federalni zakon o prijenosu tehnologije (FTTA) ${ }^{31}$ izmijenio je StevensonWydlerov zakon premještanjem naglaska u saveznoj politici s one koja dopušta prijenos tehnologije na onu koja zahtijeva da agencije energično djeluju u saradnji s industrijom kako bi komercijalizirale istraživanja koja se finansiraju od strane države. U takozvanim ugovorima o kooperativnom istraživanju i razvoju (CRADA) dozvoljeni su i ekskluzivni uslovi licenciranja.

Ova intervencija američkog zakonodavstva imala je višestruke i dalekosežne posljedice. Otvorila je put za suštinsku promjenu pristupa javno finansiranim rezultatima istraživanja, jer je ne samo ohrabrila, već je zapravo i obvezala univerzitete i druge institucije koje se finansiraju iz javnih fondova da komercijaliziraju rezultate istraživanja postignute federalnim fondovima, tj. da ih učine vlasničkim što je više moguće a federalna vlada postala je treći igrač u igri. Iako su ukupan socijalni i ekonomski uticaj Bayh-Dole-ovog zakona i ostalih američkih zakonodavnih mjera često dovođeni u pitanje, ${ }^{32}$ nepobitna je činjenica da su američki univerziteti i federalno finansirane istraživačke institucije od 1980-ih igrale ključnu ulogu kao generator novih znanja, kao i njihov prevodilac u inovacije. Godišnje statistike koje objavljuje Američko udruženje univerzitetskih tehnoloških menadžera (AUTM) to već dugo pokazuje. Njihovo Istraživanje o aktivnostima izdavanja dozvola iz 2018. godine otkriva da su članovi stvorili 825 novih proizvoda, osnovali 1.080 novoosnovanih preduzeća, podnijeli 17.087 novih prijava patenata,

\footnotetext{
${ }^{29}$ Public Law 96-517.

${ }^{30}$ Public Law 96-480.

${ }^{31}$ Public Law 99-502.

${ }^{32}$ Usp., npr. Mowery \& Nelson \& Sampath \& Ziedonis, The Growth of Patenting and Licensing by US Universities: An Assessment of the Effect of the Bayh-Dole Act of 1980, 2001:99-119; a što se tiče kritičara Frangioni, The Impact of Greed on Academic Medicine and Patient Care, 2008:503-507.
} 
izvršili 9.350 licenci i opcija i dobili 7.625 američkih patenata. ${ }^{33}$ Ukupni prihodi američkih univerziteta od njihovih licenciranja u 2018. godini iznosili su 2,94 milijarde američkih dolara. Pod pretpostavkom prosječne stope tantjema po osnovu autorskih prava od $2 \%$, akademska tehnologija bila je odgovorna za prodaju proizvoda u iznosu od oko 147 milijardi američkih dolara. ${ }^{34}$ Statistika za period 2015-2019. otkriva da su univerziteti bili vrlo aktivni, ako ne i dominirali u biotehnološkim patentima. Među prvih 20 akademskih centara rangiranih po broju izdanih biotehnoloških patenata, svi osim jednog (Univerzitet u Tokiju koji je zauzeo 17. mjesto) bili su američki, pri čemu su University of California System (1.557 patenata), Stanford University (658 patenata), University of Texas System (531 patenata), Massachusetts Institute of Technology (519 patenata) i University of Pennsylvania (495 patenata) rangirani na prvih 5 mjesta. ${ }^{35}$ Patentiranje je, međutim, skupo. Samo u 2018. godini američki univerziteti potrošili su više od 425 miliona američkih dolara na troškove vezane za patente. ${ }^{36}$

Međutim, same statistike patenata ne predstavljaju "opipljiv ishod" sve veće saradnje između federalno finansiranih istraživanja i industrije od usvajanja zakonodavnih mjera iz 1980-ih. U tom pogledu najupečatljiviji su zbirni podaci o broju lijekova razvijenih iz izuma koje su istraživačke institucije javnog sektora (PSRI) generirale samostalno ili zajednički, zaštićenih pravima intelektualnog vlasništva specifičnim za lijekove, a koji su zatim prebačeni na kompanije putem komercijalnih licenci. ${ }^{37}$ Ovi podaci otkrivaju da su, između 1991. i 2006. godine, na osnovu rezultata istraživanja PSRI-a, razvijena 153 lijeka (tj. odobrila ih je i Federalna uprava za lijekove (FDA)), uključujući 22 koja su razvijena iz Intramuralnog programa istraživanja Nacionalnog

\footnotetext{
${ }^{33}$ AUTM 2018 Licensing Activity Survey: A Survey of Technology Licensing and Related Activity for US Academic and Nonprofit Research Institutions, str. 4 (https://autm.net/ AUTM/media/SurveyReportsPDF/AUTM_FY2018_US_Licensing_Survey.pdf (posljednji pristup 18. februara 2021).

${ }^{34}$ Usp. Dipanjan \& Gupta \& Turo, The Evolution of University Technology Transfer: By the Numbers, 2020. (https://researchgate.net/publication/340766806 (posljednji pristup 20. februara 2021).

${ }^{35}$ Usp. za detalje Huggett \& Paisner, Biotech Patenting 2019, 2020:921-922.

${ }^{36}$ Prema Dipanjan \& Gupta \& Turo, supra br. 26.

${ }^{37}$ Kako je definisano u Stevens \& Jensen \& Wyller \& Kilgore \& Chatterjee \& Rohrbaugh, The Role of Public-Sector Research in the Discovery of Drugs and Vaccines, 2011:535-541, str. 537. Ovi autori naglašavaju da je u većini slučajeva intelektualno vlasništvo bilo patent ili patentna prijava, ali da je nekoliko proizvoda koristilo zaštićene biološke materijale koje je razvio i licencirao PSRI.
} 
instituta za zdravlje (NIH-IRP) $)^{38}$, za koje su patentne prijave podnesene oko 1985. (s jednim izuzetkom), a patenti su dodijeljeni između 1991. i 2007. ${ }^{39}$ Terapijska područja za 153 lijeka bila su onkologija (40), zarazne bolesti (36), kardiologija (12), imunologija (6) i drugi (59). ${ }^{40}$ Izuzetan uticaj koji su lijekovi i biološki lijekovi koje je razvio i patentirao samo NIH imali i još uvijek imaju na javno zdravstvo širom svijeta proizlazi iz činjenice da su lijekovi i biološki lijekovi koji još uvijek imaju dozvolu NIH-a ostvarili prodaju od 4,7 milijardi američkih dolara u 2010. Pored toga, prodaja za lijekove i biološke lijekove za koje su patenti istekli (koji nisu više pod licencom NIH) iznosila je oko 2,2 milijarde američkih dolara u 2010. Dakle, ukupna svjetska prodaja u 2010. godini samo za izume NIH Intramuralnog programa iznosila je najmanje 6,9 milijardi američkih dolara. ${ }^{41}$ Instrumentalna uloga koju su patenti $\mathrm{NIH}-\mathrm{a}$ odigrali u postizanju tako impresivnih i korisnih 'opipljivih' rezultata, trebala bi biti očigledna.

\section{(b) Neki od sljedbenika}

\section{(i) Japan}

Zakonodavni potezi SAD-a iz 1980-ih, koji su čvrsto integrirali javno finansirana akademska istraživanja u nacionalnu strategiju inovacija, nisu samo nadahnuli ekonomiste da usmjere svoju pažnju na veze između industrije i akademske zajednice, ${ }^{42}$ već su na međunarodnom planu djelovali i kao poti-

\footnotetext{
${ }^{38}$ Usp. Chatterjee \& Rohrbaugh, NIH Inventions Translate into Drugs and Biologics with High Public Health Impact, 2014:52-58, tabela 3 (str. 54).

${ }^{39}$ Ibid, tabela 1 (str. 53). Osnovni aplikant bio je Nacionalni institut za istraživanje raka sa 12 prijava patenata, i izdati patenti po tom osnovu (tabela 1 (str. 53)).

${ }^{40}$ Ibid, tabela 3 (str. 54).

${ }^{41}$ Ibid (str. 56-57).

${ }^{42}$ Ovdje se može referirati samo na selekciju: Collier, Alan, Australian Framework for the Commercialization of University Scientific Research, 2007:51-68; Eun \& Lee \& Wu, Explaining the "University-run Enterprises" in China: A Theoretical Framework for University-Industry Relationship in Developing Countries and its Application to China, 2006:1329-1346; Abetti, University Incubators as Agents for Technology Transfer and Economic Growth: Case Studies in USA, Ukraine and Finland, 2006:308-337; Rubenstein \& Heisey \& King, Public Sector Technology Transfer Through Patents and Licensing: The Case of US Agriculture, 2006:401-420; Steenhuis \& Gray, The University as the Engine of Growth: An Analysis of How Universities can Contribute to the Economy, 2006:421-432; Walsh \& Cohen \& Cho, Where Excludability Matters, Material vs. Intellectual Property in Academic Biomedical Research, 2007:1184-2003; Chaves \& Moro, Investigating the Interaction and Mutual Dependence Between Science and Technology, 2007:1204-1220; Woolgar, New Institutional
} 
caj za aktivnosti mnogih drugih zakonodavaca. Sve te aktivnosti imale su za cilj kreiranje nacionalnih politika za inovacije, uzimajući u obzir važnu ulogu koju akademska istraživanja moraju igrati u tom kontekstu.

Najbliži sljedbenik bio je Japan, gdje je parlament 1995. godine donio Osnovni zakon o nauci i tehnologiji. Godine 1996. usvojen je prvi, a 2001. drugi Osnovni plan za nauku i tehnologiju. Potonjim je uspostavljeno novo Vijeće za nauku i tehnologiju, povezano direktno sa Uredom vlade. ${ }^{43}$ Japanski parlament je 1998. godine usvojio Zakon o promociji transfera tehnologije sa univerziteta u privatno poslovanje. ${ }^{44}$ Implementacijom Osnovnog zakona o nauci i tehnologiji, u oktobru 2003. godine Japan je transformisao svoju Naučno-tehnološku korporaciju (JST) u Japansku agenciju za nauku i tehnologiju (JST) kao nezavisnu administrativnu instituciju. Zadatak Agencije je ojačati infrastrukturu za promociju nauke i tehnologije i provesti inicijative utvrđene Osnovnim zakonom. ${ }^{45}$ U 2017. godini, JST je posjedovao 3.604 patenta širom svijeta i podnio je 75 patentnih prijava. ${ }^{46} \mathrm{Na}$ svojoj web stranici JST nudi odabrane tehnologije za licenciranje, čineći tako sve informacije o odgovarajućim patentima / patentnim prijavama dostupnim online. ${ }^{47}$ Međutim, do sada postignuti rezultati intenzivnih i dugotrajnih napora japanske vlade na promoviranju saradnje univerziteta i industrije s ciljem poticanja nesmetanog prevođenja akademskih istraživanja u inovativne i tržišne proizvode i procese čine se skromnim. Izravno uključivanje vlade u strukturu i funkcionisanje univerziteta, ograničeno prihvatanje ekskluzivnog licenciranja rezultata državno finansiranih istraživanja od strane privatnog biznisa i

Policies for University-Industry Links in Japan, 2007:1261-1274 and D`Este, \& Patel, University-Industry Linkages in the UK: What are the Factors Underlying the Variety of Interactions with Industry? 2007:1295-1313.

${ }^{43}$ Usp. Edgington, The Japanese Innovation System: University-Industry Linkages, Small Firms and Regional Technology Centers, 2008:1-19 (str. 10 et seq). Za inicijative politika koje promoviraju veze između univerziteta i industrije u Japanu pogledajte i Walsh \& Baba \& Goto \& Yasaki, Promoting University-Industry Linkages in Japan: Faculty Responses to a Changing Policy Environment, 2008:39-54; te Holroyd, Reinventing Japan Inc.: TwentyFirst Century Innovation Strategies in Japan, 2008:21-38.

${ }^{44}$ Act No. 52 of May 6, 1998 (English translation WIPO) (https://www.wipo.int/edocs/ lexdocs/laws/en/jp/jp193en.pdf - posljednja posjeta 22. februara 2021). Usp. i Fujisue, Promotion of Academia-Industry Cooperation in Japan - Establishing the "Law of Promoting Technology Transfer from University to Industry", 1998:371-381.

${ }^{45}$ See https://www.jst.go.jp/EN/about/history.html (posljednji pristup 20. februara 2021).

${ }^{46}$ See https://www.jst.go.jp/EN/about/jstdata.html (posljednji pristup 20. februara 2021).

${ }^{47} \mathrm{See}$ https://www.jst.go.jp/chizai/en/univ-ip/cips/licensing/details_01.html (posljednji pristup 20. februara 2021). 
činjenica da univerziteti nisu direktni korisnici prihoda od licenciranja, može biti kombinirani razlog za takvu situaciju. ${ }^{48}$

Kao i u SAD-u, tako i u Japanu, univerziteti su posebno aktivni u patentima u području nauka o životu. U junu 2008. godine, Univerzitet u Kjotu, na kojem su istraživači bili vrlo uspješni u području tehnologije indukovanih pluripotentnih matičnih ćelija (iPS), osnovao je kompaniju iPS Academia Japan Inc., čiji je cilj licenciranje tehnologije iPS-ćelija. Od januara 2016. godine, iPS Academia ima status službene organizacije za prenos tehnologije prema Zakonu o unapređenju transfera tehnologije između univerziteta $\mathrm{i}$ industrije iz 1998. godine. ${ }^{49} \mathrm{U}$ svom portfelju, koji je popunjen ne samo iz prava Univerziteta u Kjotu već i iz prava drugih japanskih univerziteta, pa čak i nekih stranih institucija, iPS Academia je 2012. godine imala oko 450 prijava patenata (oko 125 porodica patenata), među kojima oko 200 njih za koje su do septembra 2016. godine patenti već bili dodijeljeni u Japanu, SAD-u, Evropi i nekim drugim zemljama. ${ }^{50}$ Prema svojim smjernicama za licenciranje, iPS Academia omogućava neprofitnim organizacijama besplatno korištenje njihovog intelektualnog vlasništva u obrazovne svrhe, pod uslovom da ne postoji komercijalni cilj. Što se tiče komercijalnih subjekata, oni u principu mogu sticati neekskluzivne licence samo pod razumnim uslovima. Međutim, od promjena smjernica iz oktobra 2015. godine, u izuzetnim slučajevima, kada su uključene neplatformske tehnologije, komercijalni subjekti mogu dobiti ekskluzivne licence. ${ }^{51}$ Do 2018. godine, iPS Academia je dodijelila 96 licenci japanskim, 29 američkim i 21 evropskim kompanijama. Među njima su farmaceutski giganti kao što su Ajinomoto i Sumitomo iz Japana i, npr. Boehringer Ingelheim, Roche i Sanofi iz Evrope..$^{53}$

\footnotetext{
${ }^{48} \mathrm{Za}$ detaljnu analizu razvoja u Japanu do 2003. godine usp. Kneller, University-Industry Cooperation and Technology Transfer in Japan Compared with the United States: Another Reason for Japanese Malaise? 2003:329-449 (str. 347-449).

${ }^{49}$ Vidi http://ips-cell.net/e/about/outline.html (posljednji pristup 21. februara 2021).

${ }^{50}$ Vidi http://ips-cell.net/e/patent/ (posljednji pristup 21. februara 2021).

${ }^{51}$ Vidi http://ips-cell.net/e/license/policy.html (posljednji pristup 21. februara 2021).

${ }^{52}$ Vidi http://ips-cell.net/e/license/licensees.html (posljednji pristup 21. februara 2021). Usp. i Straus, Patentierung und Kommerzialisierung im Bereich der Stammzellforschung, 2018:237-276 (str. 244-245).

${ }^{53}$ Kao i Japan, Korea i Taiwan su kasnih 1990-ih usvojili slične osnovne zakone o nauci i tehnologiji. Omogućili su institucijama višeg obrazovanja vlasništvo u rezultatima istraživanja finansiranih od strane vlade, te su otvorili put njihovom decentraliziranom licenciranju. Usp. Chang \& Chen \& Yang \& Hua, Universities as Patent- and Licensing Income-Generating Institutions: A survey in Taiwan, 2008:290-309 (str. 292).
} 


\section{(ii) Kina}

Nedugo nakon Japana, Narodna Republika Kina je 15. maja 1996. godine usvojila Zakon o unapređenju transformacije naučnih i tehnoloških dostignuća, koji je stupio na snagu 1. oktobra 1996. Važna izmjena tog zakona stigla je Predsjedničkom naredbom br. 32, 29. avgusta 2015. godine, koja je stupila na snagu 1. oktobra 2015. godine. ${ }^{54}$ Kao što proizlazi iz njegovog člana 1, zakon je razvijen u svrhu promocije transformacije naučnih i tehnoloških dostignuća u stvarne proizvodne snage, standardizacije takve transformacije, ubrzavanja naučnog i tehnološkog napretka i promicanja ekonomskog i socijalnog razvoja. Njegova 52 člana predstavljaju sveobuhvatan i koherentan pravni okvir čiji je cilj uspješno prevođenje nalaza istraživanja "državnih institucija za istraživanje i razvoj i institucija visokog obrazovanja" u inovativnu praksu. Te institucije mogu svoja naučna dostignuća prenijeti na preduzeća ili druge organizacije dodjelom, licencom, ulaganjem kao zamjenom i drugim sredstvima. Međutim, oni djeluju na temelju vlastitih neovisnih odluka, s cijenama koje se određuju prema ugovorenim cjenama, uvrštavanjem na tržište razmjene tehnologija, aukcijama i na druge načine. U slučaju određivanja cijena prema dogovoru, bit će naznačena imena naučnih i tehnoloških dostignuća i predložene transakcijske cijene u njihovim entitetima. ${ }^{55} \mathrm{U}$ nizu odredbi navode se mjere poput uspostavljanja javne platforme za istraživanje i razvoj, pružanja tehnološke integracije, ${ }^{56}$ podrške razvoju inkubacije naučno-tehnološkog preduzeća kao naučnog i tehnološkog inkubatora preduzeća i univerzitetskih naučnih parkova. ${ }^{57}$ Štaviše, Zakonom je predviđeno da se finansijski fondovi za transformaciju naučnih i tehnoloških dostignuća uglavnom koriste kao fondovi za usmjeravanje, subvencije kamata na zajmove, fondovi subvencija, rizična ulaganja za transformaciju, ${ }^{58} \mathrm{i}$ da će država, u skladu s odredbama relevantnih poreznih zakona i propisa, implementirati porezne povlastice za aktivnosti transformacije. ${ }^{59}$ Prema članu 43. ovoga zakona, prihodi od

${ }^{54}$ PKULAW.COM [CLI Code]: CLI.1.256285(EN). Neki od kineskih autora ovaj zakon zovu “svježe revidiranim 'Bayh-Dole zakonom'," usp. npr. Wang \& Xue \& Shi, Characteristics and Logical Framework of Chinese Universities` Response to the Newly Revised ,BayhDole Act', 2021.

${ }^{55}$ Članovi 17 i 18.

${ }^{56}$ Član 31.

${ }^{57}$ Član 32.

${ }^{58}$ Član 33.

${ }^{59}$ Član 34. Prema članovima 36. i 38. država ohrabruje osiguravajuće institucije da razviju proizvode osiguranja "srazmjerne karakteristikama”. Država također ohrabruje institucije rizičnog kapitala da investiraju u ovakve projekte. 
transformacije, odnosno komercijalizacije rezultata istraživanja, postignutih unutar državnih institucija za istraživanje i razvoj i visokoškolskih ustanova, "u potpunosti će se zadržati u njima i uglavnom će se koristiti za istraživanje i razvoj u nauci i tehnologiji, za transformaciju postignuća i drugi relevantan rad, nakon što se nagrade i naknade dodijele ljudima koji su dali značajan doprinos u završetku i transformaciji naučnih i tehnoloških dostignuća povezanih sa ovim radom." Član 45. reguliše raspodjelu prihoda od "komercijalizacije" i nagradu zaposlenih za tzv. postignuća u vezi sa radom, koji su značajno doprinijeli prenijetim postignućima, i daje sljedeća zanimljiva rješenja:

“(1) Tamo gdje je naučno i tehnološko dostignuće u vezi sa radom dodjeljeno ili licencirano drugima, povući će se najmanje pedeset posto neto prihoda od dodjele ili licence takvog naučnog i tehnološkog dostignuća.

(2) Tamo gdje se naučno i tehnološko dostignuće vezano za rad koristi kao zamjena za ulaganje, povući će se najmanje pedeset posto dionica ili kapitalnih uloga nastalih iz takvih naučnih i tehnoloških dostignuća.

(3) Tamo gdje se naučno i tehnološko dostignuće u vezi sa radom provodi samostalno ili u saradnji s drugima, najmanje pet posto poslovne dobiti od primjene naučnog i tehnološkog dostignuća uzastopno se povlači tri do pet godina nakon transformacije i uspješne proizvodnje istoga.

Način i iznos nagrada i naknada koje javno održavane istraživačke i razvojne institucije i visokoškolske ustanove odrede ili dogovore sa naučnim i tehničkim osobljem moraju biti u skladu sa kriterijima navedenim u tački (1) do tačke (3) prethodnog stava.

Državna preduzeća i javne ustanove, u skladu sa odredbama ovog zakona, uključuju izdatke za nagrade i naknade koji se dodjeljuju ljudima koji su dali značajan doprinos završetku i transformaciji naučnih i tehnoloških dostignuća u vezi sa radom u njihove ukupne plate u tekućoj godini, ali navedeni izdaci neće biti predmet ograničenja njihovih ukupnih plata u tekućoj godini i neće biti uključeni u njihovu ukupnu osnovicu plata."

Empirijski podaci o rezultatima ovog kineskog zakonodavstva nisu dostupni. Međutim, statistike o patentnim prijavama koje su podnijeli kineski univerziteti i javne istraživačke institucije poput Kineske akademije nauka (CAS) jasno otkrivaju da su oni vrlo aktivni. Naprimjer, u području tehnologija umjetne (AI) inteligencije, kineske organizacije čine 17 od 20 najboljih akademskih igrača na svijetu, a CAS je zauzeo 17. mjesto u prvih $100 \mathrm{svih}$ prijavitelja. Statistike prijava patenata povezanih sa AI otkrivaju generalno 
visoku aktivnost univerziteta i javnih istraživačkih institucija. Među prvih 500 od svih prijavitelja, 167 je akademskih institucija, od toga 110 kineskih. ${ }^{60}$

\section{(c) Evropa}

Iako je Evropa također zamijetila Bayh-Doleov zakon i druga povezana američka zakonodavna zbivanja iz 1980-ih, i unatoč prijedlozima za slijeđenje američkog primjera, ${ }^{61}$ evropski zakonodavci i na razini unije i na nacionalnoj razini do danas se opiru bilo kakvoj vrsti regulativa nalik na Bayh-Doleov zakon. Umjesto toga, dizajnirali su model sporazuma za industrijsko-akademske odnose. U svojoj Preporuci 2008/416 od 10. aprila 2008. o upravljanju intelektualnim vlasništvom u aktivnostima prenosa znanja i Kodeksu prakse za univerzitete i druge javne istraživačke organizacije, ${ }^{62}$ Evropska komisija je preporučila da države članice, između ostalog, osiguraju da sve javne istraživačke organizacije (PRO) definiraju transfer znanja kao stratešku misiju. Dalje, da podstaknu PRO-e da uspostave i objavljuju politike i postupke za upravljanje intelektualnim vlasništvom u skladu sa Kodeksom prakse, podržavaju razvoj kapaciteta i vještina za prijenos znanja u PRO-ima, podižu svijest $\mathrm{i}$ vještine učenika u vezi sa intelektualnim vlasništvom, prijenosom znanja i preduzetništvom, i da promoviraju širenje znanja stvorenog javnim sredstvima. Sve to poduzimanjem koraka za poticanje otvorenog pristupa rezultatima istraživanja, istovremeno omogućavajući, prema potrebi, zaštitu srodnih intelektualnih prava, itd. ${ }^{63}$

U svojoj Studiji o prijenosu znanja, Evropska komisija prepoznala je da su evropske javne istraživačke institucije manje efikasne u komercijalizaciji rezultata istraživanja i generiranju otkrića pronalazaka, prijava patenata ili prihoda od licenci u poređenju sa američkim kolegama. Da bi zaradile jedan milion eura prihoda od licenci, Evropske javno finansirane istraživačke institucije troše u prosjeku 3,3 puta više za istraživanje nego američke javno finansirane istraživačke institucije. ${ }^{64}$ Studija je otkrila da većina evropskih institucija

\footnotetext{
${ }^{60}$ Usp. WIPO Technology Trends 2019 - Artificial Intelligence, 2019:16-17; i Straus, Artificial Intelligence - Challenges and Chances for Europe, 2021:142-158 (str.146-147).

${ }^{61}$ Usp. Straus, The Present State of the Patent System in the European Union, 1997. (fusnota 111 (str. 55 i 56) i Suggestion xiii (str. 63)).

${ }^{62}$ Usp. EU Commission, OJ EC No. L 146, 2008:19.

${ }^{63}$ Usp. i Collins, European Tools up for Industry-Academic Collaborations, 2006:2-4, u kojem se izvještava o tzv. Lambert Agreement modelu ugovora u UK.

${ }^{64} \mathrm{https}$ ://ec.europa.eu/research/innovation-union/pdf/knowledge_transfer_2010-2012_report. pdf (posljednji pristup 25. februara 2021), str. 128-129.
} 
uključenih u komercijalizaciju rezultata akademskih istraživanja gubi novac, uprkos bogatom izvoru intelektualnog vlasništva. S ciljem poboljšanja efikasnosti prijenosa intelektualnog vlasništva i tehnologija od strane istraživačkih institucija javnog sektora u industriju putem ugovora o istraživanju i razvoju, licenciranja i izdvajanja, Komisija je pokrenula poziv za Izgradnju kapaciteta u transferu tehnologije. ${ }^{65}$ Taj poziv rezultirao je trogodišnjim projektom Progress-TT - "Public Research Organization Growing Europe through best practice Solutions for Technology Transfer". Ipak, Evropa još uvijek daleko zaostaje za Sjedinjenim Američkim Državama u pogledu transfera znanja i tehnologija iz akademske zajednice u industriju. Bez obzira na to, institucije poput Oxford University Innovation (OUI), Oxford Nanopore Technologies i University College London Business iz Velike Britanije, njemački Max Planck Innovation i francuski CERN primjeri su uspješne komercijalizacije rezultata istraživanja njihovih institucija. Brojni patenti, ugovori o licenciranju i novoosnovana preduzeća svjedoče o tom uspjehu. ${ }^{66}$

\section{(d) Njemačka}

Nadahnuti američkim zakonodavnim dešavanjima, koja su suzila akademsku slobodu javno finansiranih istraživača i njihovih poslodavaca da objavljuju i slobodno šire svoje istraživanje, njemački zakonodavci su 2002. godine iz temelja revidirali odgovarajuću odredbu Zakona o izumima zaposlenih. ${ }^{67}$ Na osnovu ustavnog prava na slobodu nauke i istraživanja iz člana 5. stavka 3. Njemačkog osnovnog zakona (Grundgesetz - Ustava), član 42. stavak 1. Zakona, propisivao je da izumi profesora, predavača i naučnih asistenata $u$ njihovom kapacitetu kao takvih na univerzitetima i višim naučnim školama bit će slobodni izumi. To znači da su pripadali svojim pronalazačima bez ikakvih ograničenja i da su stoga mogli biti objavljeni ili prijavljeni za patent po njihovom nahođenju. Izmijenjeni član 42. Zakona sad propisuje da izumi zaposlenih na univerzitetima i drugim visokoškolskim ustanovama, što se tiče prava na njih, u načelu podliježu istim pravilima predviđenim Zakonom

\footnotetext{
65 https://ec.europa.eu/info/funding-tenders/opportunities/portal/screen/opportunities/topicdetails/cbtt-1-2014 - posljednja posjeta 25. februara 2021.

${ }^{66}$ Usp. ALLEA Statement "The Need for Intellectual Property Rights Strategies at Academic Institutions" (https://allea.org/wp-content/uploads/2019/11/The_Need_for_IPR_Strategies_at_Academic_Institutions_ALLEA_2019-1.pdf - posljednja posjeta 25. februara 2021), 2019:6-7, sa daljnjim referencama.

${ }^{67}$ Federal Official Journal 2002 I, 2002:414.
} 
o izumima svih ostalih zaposlenika. Međutim, suprotno općenitom pravilu, ova grupa pronalazača ima pravo otkriti svoje "izume u radu" u okviru svojih nastavnih ili istraživačkih aktivnosti, pod uslovom da su na vrijeme (u pravilu, dva mjeseca unaprijed) poslodavcu prijavili svoj izum (Član 42 (1) br. 1). Štaviše, u slučaju da izumitelj odluči da ne iznese svoj izum tokom svojih nastavnih i istraživačkih aktivnosti, on uopšte nije dužan da obavijesti poslodavca o svom izumu na radu. Još jedna temeljna razlika koja postoji između izuma na radu univerzitetskog osoblja i izuma svih ostalih zaposlenih odnosi se na nagradu koju poslodavac (tj. Univerzitet) mora platiti izumitelju u slučaju eksploatacije izuma koji je stekao. Statutom je ta nagrada utvrđena na $30 \%$ od ostvarenog dohotka (član 42 (4)), što je mnogo više od one koja se izračunava za druge pronalazače među zaposlenicima. Savezna vlada Njemačke iskoristila je nekoliko miliona eura iz milijardi generisanih aukcijama Univerzalnog mobilnog telekomunikacijskog sistema (UMTS) za finansiranje infrastrukture neophodne da univerzitetima omogući da preuzmu zadatak prijenosa znanja i tehnologija. Osnovano je 19 profesionalnih agencija za patentiranje i eksploataciju javno finansiranih istraživanja koja su 2002. godine počela obučavanje 170 univerziteta i 40 manjih istraživačkih institucija. ${ }^{68}$ Teško je procijeniti koliko je uspješna bila takozvana "eksploatacijska ofanziva" Savezne vlade. Nedavno su izašle na vidjelo kritike nezadovoljnih fakulteta zbog njihovog udjela u prihodima, pa čak i ukazivanje na to da neki profesori koriste "lažnjake" kao podnosioce patentnih zahtjeva kako bi zaobišli svoje zakonske obaveze i održali svoje uspostavljene industrijske veze. ${ }^{69}$

Odlukom od 18. septembra 2007. godine, ${ }^{70}$ Njemački savezni vrhovni sud priznao je, s jedne strane, da obaveza profesora i ostalog univerzitetskog osoblja da na određeno vrijeme odlože objavljivanje rezultata istraživanja koji su u osnovi izuma zaista utječe na slobodu nauke, tj. na akademske slobode. S druge strane, međutim, Sud je smatrao da sloboda istraživanja i podučavanja ne zahtijeva vlasništvo nad pravima eksploatacije rezultata istraživanja koji su pridruženi profesoru. Sud je, osim toga, primijetio da član 5 (3) Osnovnog zakona ne kontrolira samo pojedinačna prava, već predstavlja i osnovnu normu koja sadrži vrijednosnu prosudu koja regulira odnos između nauke i države. Prema ovoj osnovnoj normi, država mora poduzeti odgovarajuću organizaciju

\footnotetext{
${ }^{68}$ Usp. odgovor Savezne vlade od 21. avgusta 2002. u Bundestagu (Saveznom parlamentu), Drucksache 14/9874, str. 26.

${ }^{69}$ Usp. Technologietransfer kommt nicht in Schwung (bez autora), Handelsblatt od 3. marta 2021, https://www.handelsblatt.com/politik/deutschland/verwertunsoffensive-der-bundesre...

${ }^{70}$ GRUR Int. 2008:251-254 (at 254) - Freedom of Publication.
} 
i mjere na području javno finansiranih istraživanja kako bi osnovno pravo na besplatnu naučnu djelatnost ostavila netaknutom u onoj mjeri u kojoj je to moguće uzimajući u obzir druge legitimne zadatke naučne institucije i ustavna prava ostalih uključenih. U tom kontekstu, Sud je pojasnio da dotični zadaci moraju predstavljati pravne vrijednosti ustavnog rangiranja, ali smatrao je da se prikupljanje sredstava univerziteta, uključujući iz grupe patentabilnih izuma njegovog osoblja, odnosi na operativnu sposobnost univerziteta koji ima takav ustavni rang.

Novo pravilo uvedeno 2002. godine, prema razumijevanju Suda, uzima u obzir fiskalni interes države, kako bi se omogućilo univerzitetima da steknu finansijska sredstva od eksploatacije svojih izuma. Dalje je naglasio da je prikupljanje sredstava od izuma zaposlenih na univerzitetima, u principu, bilo primjereno za jačanje ekonomije univerziteta. $\mathrm{S}$ obzirom na to da u njemačkom Zakonu o patentima nema grejs perioda za novine, Sud je dalje primijetio da je za osiguranje legitimnih interesa univerziteta neophodno da zakonodavac uvede pravilo koje sprečava prerano otkrivanje izuma. Nadalje, sve dok se od univerziteta nije očekivalo ili se od njih tražilo da odustanu od osnovnih istraživanja ili da ih izvrše samo u ograničenoj mjeri i koncentriraju se na specifične projekte koji su pogodniji za komercijalnu eksploataciju, to ne predstavlja pomjeranje istraživačkog mandata univerziteta sa slobodnog osnovnog istraživanja bez konkretne svrhe na istraživanje usmjereno na učinkovitu komercijalnu upotrebu. Dakle, ovo ne krši ustavno pravo na slobodu istraživanja i podučavanja. Takvo obrazloženje, međutim, prema mišljenju suda ne može se zaključiti iz člana 42 revidiranog Zakona o izumima zaposlenih.

\section{Prava intelektualnog vlasništva}

\section{(a) Osnovne karakteristike}

Prema članu 1 (2) Međunarodnog sporazuma o trgovinskim aspektima prava intelektualnog vlasništva (TRIPS) iz 1994. godine, koji je uveo standarde zaštite obavezne za sve države članice Svjetske trgovinske organizacije (WTO), pojam "intelektualno vlasništvo" pokriva patente, autorska i srodna prava, zaštitne znakove, industrijske dizajne, geografske oznake, nacrte (topografije) integrisanih krugova i neotkrivene informacije. Zajednička karakteristika svih ovih prava je da se sva ona odnose na nematerijalne sveprisutne rezultate ljudskog stvaralačkog poduhvata. U ovom kontekstu, a koji je od posebnog značaja za istraživačke aktivnosti akademske zajednice, su i patenti i autorska prava. 
Patenti se odnose na nove, ne očigledne i industrijski primjenjive izume, ${ }^{71}$ tj. upute za rješavanje tehničkih problema tehničkim sredstvima. Otkrića kao takva ne predstavljaju predmet patentiranja. Međutim, primijenjena otkrića, tj. konkretna tehnička učenja, a ne teorijsko objašnjenje dato za njeno funkcioniranje, u principu su prihvatljiva za patent. Naprimjer, član 3. stav 2. Direktive 98/44/EC Evropskog parlamenta i Vijeća o pravnoj zaštiti biotehnoloških izuma iz 1998. godine ${ }^{72}$ navodi da: "Biološki materijal koji je izoliran iz svog prirodnog okoliša ili je proizveden pomoću tehničkog postupka može biti predmet izuma čak i ako se prethodno pojavljivao u prirodi." Ovo se odnosi i na elemente izolirane iz ljudskog tijela, uključujući sekvencu ili djelomičnu sekvencu gena (član 5 (2) Direktive). ${ }^{73}$

Autorska prava se odnose na književna i umjetnička djela, uključujući svaku produkciju u književnom, naučnom i umjetničkom domenu, bez obzira na način ili oblik njenog izražavanja. Autorska prava također pružaju zaštitu za računarske programe, bilo u izvornom ili objektnom kodu, kao i za kompilaciju podataka prema članu 2 (1) Bernske konvencije za zaštitu književnih i umjetničkih djela iz 1886. godine (poslednji put revidirana 1971. godine) (u vezi sa članom 10 TRIPS-a).

I patenti i autorska prava su ekskluzivna prava ograničena vremenom. Patenti su u pravilu ograničeni na 20 godina, koje se računaju od datuma podnošenja. ${ }^{74}$ Trajanje zaštite autorskih prava je najmanje životni vijek autora i 50 godina nakon njegove smrti, ili, ako se računa na osnovi koja nije život fizičke osobe, najmanje 50 godina od kraja kalendarske godine odobrenog objavljivanja, ili, ukoliko takva ovlaštena publikacija ne izađe, u roku od 50 godina od nastanka djela ili 50 godina od kraja kalendarske godine nastanka

\footnotetext{
${ }^{71}$ Član 27. (1) TRIPS-a zahtijeva od svih članica WTO-a da obezbijede patente za bilo koje izume, bili oni proizvodi ili procesi, u svim poljima tehnologije, pod uslovom da su oni novi, uključuju inovativne korake (,nisu očigledni') i imaju mogućnost industrijske primjene (,korisni‘ su). Za detalje, posebice za izuzetke dozvoljene prema članu 27. (2) i (3) TRIPS-a, vidi Straus, Implications of the TRIPS Agreement in the Field of Patent Law, 1996:160-215. ${ }^{72}$ OJ EC No. L 213/13 of August 30, 1998.

${ }^{73} \mathrm{Za}$ specifični problem patentiranja matičnih ćelija ljudskog embrija vidi Straus, Research, Exploitation and Patenting in the Area of Human Embryonic Stem Cells in Europe - A Case of Concern Causing Inconsistency, 2017:107-120.

${ }^{74}$ Član 33. TRIPS-a. U velikom broju država, npr. u SAD-u, Japanu i članicama EU, u slučaju farmaceutskih i agrohemijskih proizvoda, može se postići produženje roka na osnovu tzv. Dodatnog zaštitnog certifikata (Supplementary Protection Certificate - SPC) u trajanju do 5 godina, kako bi se kompenziralo za period vremena potrebnog za dobivanje tržišnog odobrenja.
} 
djela. ${ }^{75}$ Osim pojma zaštite, dvije kategorije prava intelektualnog vlasništva najvažnije za akademski svijet razlikuju se i u nizu drugih aspekata, od kojih treba spomenuti samo sljedeće: autorska prava ne zahtijevaju bilo kakve formalnosti, već štite autora, u principu, samo od "kopiranja", ali ne i od nezavisnih kreacija. Također se odnosi samo na oblik izražavanja, tj. ne štiti sadržaj kreacije. Patenti u većini patentnih zakona zahtijevaju skupe formalne postupke za dodjelu patenata uz ispitivanje uslova za patentiranje. Patenti su "blokirajuća prava", tj. oni su učinkoviti i protiv neovisnih izumitelja, koji se nisu prijavili za patent ili su to učinili samo s kasnijim prioritetom.

Kao instrument ekonomske politike, prava intelektualnog vlasništva pružaju poticaje i nagrađuju širok spektar korisne ljudske kreativnosti. Ona posebno igraju ključnu ulogu kao poticaj i zaštita rizičnog ulaganja u istraživanje i razvoj. Važno je naglasiti da prava intelektualnog vlasništva postižu svoje makro-, ali i mikroekonomske učinke samo putem tržišnih mehanizama, za koje čine važan, pa čak i neophodan instrument. Nisu sami patenti, koji svojim nosiocima osiguravaju ekskluzivna prava na eksploataciju, ti koji nagrađuju izumitelje i izume, već njihov uspjeh na tržištu u konkurenciji sa tehničkim i ekonomskim alternativama. Na vlasnicima prava intelektualnog vlasništva je da potraže takve mogućnosti i odaberu one najperspektivnije. ${ }^{76}$ Zbog ovih mehanizama, svojstvenih sistemu intelektualnog vlasništva, samo su američke zakonodavne aktivnosti 1980-ih mogle sinhronizirati aktivnosti istraživačkih institucija javnog sektora s privatnim istraživačko-razvojnim aktivnostima i optimalno iskoristiti njihove potencijale. Iako važnost prava intelektualnog vlasništva, posebno patenata, iz sasvim očiglednih razloga u velikoj mjeri ovisi o određenoj grani industrije i najviše je cijenjena u području farmaceutskih proizvoda, postalo je očito i općenito prihvaćeno da ta prava predstavljaju učinkovit i neophodan podsticaj za istraživanje i inovacije. ${ }^{77}$

\footnotetext{
${ }^{75}$ Član 7. (1) Konvencije iz Berna u vezi sa članom 12. TRIPS-a.

${ }^{76}$ Usp. Beier, Significance of the Patent System for Technical Economic and Social Progress, 1980:563-584 (str. 563).

${ }^{77}$ Usp. sveobuhvatnu analizu Sherwood, Intellectual Property Rights and Economic Development, 1990:67; Mansfield, Intellectual Property, Technology and Economic Growth, in Rushing, 1990:17-30; von Hippel, The Sources of Innovation, 1988:47; Mowery \& Rosenberg, Technology and the Pursuit of the Economic Growth, 1989:72 and Cohen \& Merrill, Introduction, 2003:3.
} 
(b) Specifični aspekti

Za uticaj koji prava intelektualnog vlasništva, posebno patenti, imaju, ili radije koji bi trebali imati, na rad akademskih istraživača, neophodno je da sistem zaštite prava intelektualnog vlasništva adekvatno uzima u obzir potrebe koje proizlaze iz njihove misije u nacionalnom inovacijskom ekosistemu.

Kao važnom generatoru patentabilnih rezultata istraživanja, akademskoj zajednici je potrebno pravno okruženje u kojem može optimalno ispuniti svoju primarnu misiju, tj. da generira nova znanja i pravovremeno ih širi, bez gubitka vlasničkih prava nad tim znanjem. Dakle, patentni sistem mora široko uključiti sve rezultate istraživanja u najnaprednijim oblastima nauke i tehnologije među predmete koji ispunjavaju uslove za zaštitu. Drugim riječima, dostignuća u genomici, proteomiki, tehnologiji matičnih ćelija, nanotehnologiji, računalno implementiranim izumima i npr. u tehnologiji umjetne inteligencije, koja u principu ispunjavaju redovne zahtjeve za patentibilnost, trebaju biti patentibilna. Štaviše, patentni sistem treba osigurati uslove u kojima željeno stavljanje na raspolaganje i širenje istraživačkih dostignuća ne rezultira automatski gubitkom vlasničkih prava. Zahvaljujući obaveznom objavljivanju prijava patenata u roku od 18 mjeseci od datuma podnošenja / prioriteta, i uslovu da se izum objelodani u prijavi patenta na dovoljno jasan i potpun način da bi ga kvalificirana osoba mogla provesti, patenti djeluju odlučno protiv tajnosti u korist ranog objavljivanja rezultata istraživanja i njihovog širenja.

Kako bi se spriječilo da bilo koja objava u naučnom časopisu ili bilo koja usmena prezentacija na konferenciji ili javna upotreba izuma automatski rezultira gubitkom prava na njegovo ekskluzivno iskorištavanje, zemlje poput Australije, Brazila, Kanade, Japana, SAD i mnogi drugi, u svojim zakonima o patentima predviđaju takozvani "grejs period". Pravilo grejs perioda predviđa imunitet protiv vlastite publikacije od strane podnosioca prijave, ako je prijava podnesena $u$ roku od šest ili dvanaest mjeseci od dana objavljivanja. ${ }^{78}$ Nažalost, Evropska patentna konvencija (EPC) i zakoni o patentima svih njenih ugovornih strana usvojili su članom 55. EPC-a uski "grejs period" koji regulira slučaj da je otkrivanje nastalo kao rezultat očigledne zloupotrebe u odnosu na podnosioca prijave ili njegovog pravnog prethodnika. Ponovljeni pokušaji evropske akademske zajednice, koje zastupa Federacija evropskih

\footnotetext{
${ }^{78}$ Usp. Straus, Grace Period and the European and International Patent Law, Analysis of Key Legal and Socio-Economic Aspects, 2001.
} 
akademija nauka i humanističkih nauka (ALLEA), ${ }^{79}$ da se standard novine izmijeni i uskladi sa standardima povoljnim za akademsku zajednicu kakve imaju neki od evropskih kolega, bili su uzaludni.

Kada je u pitanju položaj akademske zajednice kao korisnika patentiranih izuma trećih strana, patenti im ne bi trebali predstavljati ozbiljnu prepreku da imaju što je moguće slobodniji pristup najnovijim dostignućima nauke i tehnologije i koriste ih za obrazovne, eksperimentalne i istraživačke svrhe. Izuzevši od učinaka patenta, između ostalog, radnje učinjene u eksperimentalne svrhe koje se odnose na predmet patentiranog izuma i upotrebu biološkog materijala u svrhu uzgoja ili otkrivanja i razvoja drugih biljnih sorti, ${ }^{80} \mathrm{u}$ Evropi zaštita patenata ne predstavlja prepreku za dalji naučni i tehnološki razvoj. Naprimjer, Njemački savezni vrhovni sud (BGH) i Njemački savezni ustavni sud presudili su da svaki eksperiment koji se odnosi na temu patentiranog izuma i teži poboljšanju znanja, tj. za dobivanje daljnjih rezultata istraživanja, uključujući pronalaženje daljnje medicinske upotrebe patentiranog lijeka, koji je u konačnici proveden u komercijalne svrhe, ne predstavlja kršenje patenta. ${ }^{81}$

\section{Zaključci}

Događaji započeti 1980-ih u SAD-u i oni koji su uslijedili u drugim zemljama, kako je navedeno i u Njemačkoj, jasno otkrivaju evolucijsku promjenu u osnovnom razumijevanju akademske slobode u mjeri u kojoj se rezultati akademskog istraživanja javno finansiraju. Osnovno razumijevanje je da mašta i kreativnost predstavljaju važne nacionalne resurse i da sistem prava intelektualnog vlasništva olakšava i dozvoljava širenje rezultata istraživanja javnosti, kao i njihovo prevođenje u inovativne proizvode i procese. Štaviše,

\footnotetext{
${ }^{79}$ Usp. npr. ALLEA Statement on Grace Period, usvojenu na Konferenciji o ,grejs periodu` u Kijevu (https://www.allea.org/wp-content/uploads/2015/08/Statement_Grace-Period_Kiev. pdf (posljednji pristup 3. februara 2021), sazvanu od strane ALLEA-e i Ukrajinske akademije nauka (NAS).

${ }^{80}$ Član 27. (b.) i (c.) Sporazuma o zajedničkom sudu za patente, OJ EC 2013/C 175/01 of 20. 6. 2013. Iako ovaj Sporazum zbog problema sa Brexitom još uvijek nije stupio na snagu, nacionalni zakoni o patentima u državama članicama EU već pružaju ograničenja koja imaju efekt patenta.

${ }^{81}$ Usp. BGH odluke od 11. jula 1995. [1997] IIC 01, 103 - Clinical Tests, i od 17. aprila 1997. [1998] R.P.C. 423 - Clinical Trials II, te odluke Saveznog ustavnog suda od 10. maja 2000. [2001] GRUR 43 - Klinische Versuche.
} 
da je efikasno upravljanje rezultatima javno finansiranog istraživanja u javnom interesu i uključuje prava intelektualnog vlasništva.

Prema tome, prava intelektualnog vlasništva igraju važnu ulogu u bilo kojem nacionalnom naučnom sistemu. Međutim, čak i ako su optimalno prilagođena potrebama akademskih istraživača, ona su samo jedan od mnogih elemenata koji su odgovorni za uspješno funkcioniranje nacionalnog naučnog sistema. Američki izvještaj "Nauka, beskrajna granica" već 1947. godine jasno je stavio doznanja da "nauka može biti djelotvorna u nacionalnoj dobrobiti samo kao član tima". Drugim riječima, zajedno s drugim dijelovima društva. Pored neophodne finansijske podrške, naučni sistem treba i odgovarajuće pravne posljedice. Sistem intelektualnog vlasništva predstavlja samo jednu od njih. Poreski zakon, koji daje preferencijalni tretman za ulaganje u istraživanje i razvoj i za prihode ostvarene rezultatima istraživanja, te racionalne regulatorne odredbe koje se bave sigurnošću ili etikom, su drugi dio. Kao što pokazuju američko zakonodavstvo iz 1980-ih i njegovi sljedbenici u Japanu i Kini, njegovanje nacionalnih naučnih sistema zahtjevan je i složen zadatak, koji zahtijeva velike napore sva tri dijela "Triple helix" alijanse da bi bio uspješan. Da parafraziram nobelovca Karyja Banks Mullisa, izumitelja patentirane lančane reakcije polimeraze (PCR), jednog od tehnoloških stupova rDNA tehnologije, čije su riječi u uvodu ovog rada, pravo treba izbjegavati da "oslobodi" ili "porobi” nauku. Pravo treba njegovati nauku na uravnotežen način između te dvije krajnosti. Kary Mullis je vjerovatno u pravu kada kaže da nauka "svake godine raste poput korova", ali i korovu treba plodno tlo. Nikada ne treba zanemariti mudre riječi ser Charlesa Cartera: "Ne možete imati zdravu nauku u bolesnoj ekonomiji". ${ }^{82}$ Dakle, zdrava ekonomija je tlo koje je potrebno nacionalnoj nauci i ako se pravilno njeguje, nauka zauzvrat može doprinijeti zdravlju nacionalne ekonomije.

\section{Literatura}

Abbott, Frederick M. and Reichman, Jerome H. (2020). Facilitating Access to Cross-Border Supplies of Patented Pharmaceuticals: The Case of the COVID-19 Pandemic. JIEL, Vol. 23, str. 535-561

Abetti, Pierre A. (2006). University Incubators as Agents for Technology Transfer and Economic Growth: Case Studies in USA. Ukraine and Finland. Int. J. Technology Transfer and Commercialization, Vol. 5 (No. 4), str. 308-337

Act on the Promotion of Technology Transfer from Universities to Private Business Operators (Tentative translation) (1998) [Digital Edition]. Preuzeto sa https://www.wipo.int/ edocs/lexdocs/laws/en/jp/jp193en.pdf

\footnotetext{
${ }^{82}$ Sir Carter, Conditions for the Successful Use of Science, 1983: 1295-1298.
} 
Agreement on a Unified Patent Court, OJ EC 2013/C 175/01 (2013) [Digital Edition]. Preuzeto sa https://eur- lex.europa.eu/LexUriServ/LexUriServ.do?uri=OJ:C:2013:175:0 001:0040:EN:PDF

ALLEA Statement on Grace Period (2013) [Digital Edition]. Preuzeto sa https://www.allea. org/wp-content/uploads/2015/08/Statement_Grace-Period_Kiev.pdf

ALLEA Statement "The Need for Intellectual Property Rights Strategies at Academic Institutions" (2019) [Digital Edition]. Preuzeto sa https://allea.org/wp-content/uploads/2019/11/ The_Need_for_IPR_Strategies_at_Academic_Institutions_ALLEA_2019-1.pdf

Asgari, Nikou, Mancini, Donato Paolo and Kuchler, Hannah (2021). Pharma Industry Fears Biden's Patent Decision Sets Dangerous Precedent, Financial Times of May 7, 2021

AUTM 2018 Licensing Activity Survey: A Survey of Technology Licensing and Related Activity for US Academic and Nonprofit Research Institutions [Digital Edition]. Taken from https://autm.net/AUTM/media/SurveyReportsPDF/AUTM_FY2018_US_Licensing_Survey.pdf

Beier, Friedrich-Karl (1980). Significance of the Patent System for Technical Economic and Social Progress, IIC, Vol. 11, str. 563-584

Benz, Matthias and Feldges, Dominik (2021). Ein Turbo für die Impfstoff-Hersteller: Lässt sich die Produktion von Corona-Vakzinen Beschleunigen? [Digital Edition]. Preuzeto sa https://www.nzz.ch/wirtschaft/corona-impfung-moeglichkeiten-zur-beschleunigung-derproduktion-ld.1599788

Bush, Vannevar (1945). Science the Endless Frontier. [Digital Edition]. Preuzeto sa https:// www.nsf.gov/od/lpa/nsf50/vbush1945.htm.

Carter, Charles (1983), Conditions for the Successful Use of Science. Science Vol. 219 (No. 4590), str. 1295-1298

Chang, Yuan-Chieh, Chen, Ming-Huei, Yang, Phil Y. and Hua, Mingshua (2008). Universities as Patent- and Licensing Income-Generating Institutions: A survey in Taiwan. Int. J. Technology Management, Vol. 42 (No. 3), str. 290 - 309

Chatterjee, Sabarni K. and Rohrbaugh, Mark L. (2014). NIH Inventions Translate into Drugs and Biologics with High Public Health Impact. Nature Biotechnology, Vol. 32 (No. 1), str. 52-58

Chaves, Catari V. and Moro, Sueli (2007). Investigating the Interaction and Mutual Dependence between Science and Technology. Research Policy, Vol. 36 (No. 8), str. 1204-1220

Cohen, Wesley M. and Merrill, Stephen A. (2003). Patents in the Knowledge Based Economy. Study of the National Research Council of the National Academies. The National Academic Press, Washington D.C.

Collier, Alan (2007). Australian Framework for the Commercialization of University Scientific Research. Prometheus, Vol. 25 (No. 1), str. 51-68

Collins, Luke (2006). European Tools Up for Industry-Academic Collaborations. Research Technology Management, Vol. 49 (No. 5), str. 2-4

Corum, Jonathan and Zimmer, Carl (2021). How the Oxford-AstraZeneca Vaccine Works [Digital Edition]. Preuzeto sa https://www.nytimes.com/interactive/2020/health/oxfordastrazeneca-covid-19-vaccine.html

D‘Este, P. and Patel, Parimal (2007). University-Industry Linkages in the UK: What are the Factors Underlying the Variety of Interactions with Industry? Research Policy, Vol. 36, No. 8, str. 1295-1313 
Dipanjan, Nag, Gupta, Antara and Turo, Alex (2020). The Evolution of University Technology Transfer: By the Numbers [Digital Edition]. Preuzeto sa https://researchgate.net/ publication/340766806

EC Commission, Knowledge Transfer Study [Digital Edition]. Preuzeto sa https://ec.europa. eu/research/innovation-union/pdf/knowledge_transfer_2010-2012_report.pdf

Edgington, David W. (2008). The Japanese Innovation System: University-Industry Linkages, Small Firms and Regional Technology Centers. Prometheus, Vol. 26, (No. 1), str. 1-19

Etzkowitz, Henry and Leydesdorff, Loet (1997). Universities and the Global Knowledge Economy: A Triple Helix of University-Industry-Government Relations. Cassells Academic, str. 1-8

Eun, Jong-Hak, Lee, Keun and Wu, Guisheng (2006). Explaining the "University-run Enterprises" in China: A Theoretical Framework for University-Industry Relationship in Developing Countries and its Application to China. Research Policy, Vol. 35 (No. 9), str. 1329-1346

Fauci, Anthony S. (2021). The Story Behind COVID-19 Vaccines. Science, Vol. 372 (No. 6538), str. 109

Frangioni, John V. (2008). The Impact of Greed on Academic Medicine and Patient Care. Nature Biotechnology, Vol. 26, str. 503-507

Fraser, Claire M. (2021). Editorial: A Genome to Celebrate. Science, Vol. 371 (No. 6529), str. 545

Fujisue, Kenzo (1998). Promotion of Academia-Industry Cooperation in Japan - Establishing the "Law of Promoting Technology Transfer from University to Industry". Technovation, Vol. 18, (No. 6-7), str. 371-381

Gaveria, Mario and Kilic, Burcu (2021). A Network Analysis of COVID-19 mRNA Vaccine Patents. Nature Biotechnology, Vol. 39, str. 546-549

Gibson, Emily K. (2020). Overseeing Innovation: 75 Years after Vannevar Bush‘s Impactful Report, debate continuous about directing science. Science, Vol. 369 (No. 6501), str. 258-259

Hippel, Eric von (1988). The Sources of Innovation. Oxford University Press, Oxford

Hoerr, Ingmar, Obst, Reinhard, Rammensee, Hans-Georg and Jung, Günther (2000). In Vivo Application of RNA Leads to Induction of Specific Cytotoxic T-Lymphocytes and Antibodies. Eur J Immonol, Vol. 30 (No. 1), str. 1-7

Hoerr, Ingmar (2017). A Successful Founder off the Beaten Path. Nature Biotechnology, Vol. 35, (No. 10), str. 900-903

Holroyd, Carin (2008). Reinventing Japan Inc.: Twenty-First Century Innovation Strategies in Japan. Prometheus, Vol. 26 (No. 1), str. 21-38

Huggett, Brady and Paisner, Kathryn (2020). Biotech Patenting 2019. Nature Biotechnology, Vol. 38 (No. 8), str. 921-922

Jones, Kathryn M. and Cook-Deegan, Robert (2021). Complicated Legacies: The Human Genome at 20. Science, Vol. 371 (No. 6529), str. 564-569

Karikó, Katalin, Buckstein, Michael, Ni, Houping and Weissman, Drew (2005). Suppression of RNA Recognition by Toll-like Receptor: The Impact of Nucleoside Modification and the Evolution Origin of RNA. Immunity, Vol. 23 (No. 2) str. 165-175

Keener, Amanda B. (2018). Just the Messenger: A New Class of Therapeutic Instruct the Body to Make its Own Drugs, Nature Medicine, Vol. 24, str. 1294-1300 
Kneller, Robert (2003). University-Industry Cooperation and Technology Transfer in Japan Compared with the United States: Another Reason for Japanese Malaise? U. Pa. J. Int'1 Econ. L., Vol. 24 (No. 2), str. 329-449

Kolata, Gina (2021). Kati Karikó Helped Shield the World From the Coronavirus. The New York Times of April 8, 2021

Kuhn, Thomas S. (1970). The Structure of Scientific Revolutions, Second Edition, Enlarged, Vol. 2, No. 2, University of Chicago Press, Chicago/London

Leydesdorff, Loet and Etzkowitz, Henry (1996). The Future Location of Research: A Triple Helix of University-Industry-Government Relations II: EASST Review, Vol. 15 (No. 4), str. 20-25

Leydesdorff, Loet and Etzkowitz, Henry (1996). Emergence of a Triple Helix of UniversityIndustry-Government Relations. Science and Public Policy, Vol. 23, str. 279-286

Leydesdorff, Loet (2000). The Triple Helix: An Evolutionary Model of Innovations. Research Policy, Vol. 29 (No. 2), str. 243-255

Mansfield, Edwin (1990). Intellectual Property, Technology and Economic Growth. Rushing, Francis W. and Ganz-Brown, Carol (eds.), Intellectual Property Rights in Science, Technology, and Economic Performance - International Comparisons (str. 17-30), Routledge, New York

Mowery, David C. and Rosenberg, Natan S. (1989). Technology and the Pursuit of the Economic Growth. Cambridge University Press, Cambridge

Mowery, David C., Nelson, Richard R., Sampath, Bhaven N. and Ziedonis, Arvids A. (2001). The Growth of Patenting and Licensing by US Universities: An Assessment of the Effect of the Bayh-Dole Act of 1980. Research Policy, Vol. 30 (No. 1), str. 99-119

OJ EC No. L 213/13 (1998) [Digital Edition]. Preuzeto sa https://eur-lex.europa.eu/LexUriServ/LexUriServ.do?uri=OJ:L:1998:213:0013:0021:EN:PDF

OJ EC No. L 146 (2008) [Digital Edition]. Preuzeto sa https://eur-lex.europa.eu/legal-content/EN/TXT/PDF/?uri=CELEX:32008H0416\&from=EN

Peel, Michael (2021). EU Leaders Confront US over Vaccine Patent Waiver, Financial Times of May 8, 2021, str. 2

Report "A Missed Opportunity - The Patent Saga" [Digital Edition]. Preuzeto sa http://www. whatisbiotechnology.org/exhibitions/milstein/patents

Rubenstein, Kelly D., Heisey, Paul W. and King, John L. (2006). Public Sector Technology Transfer Through Patents and Licensing: The Case of US Agriculture. Int. J. Technology Transfer and Commercialization, Vol. 5 (No. 4), str. 401-420

Sherwood, Robert M. (1990). Intellectual Property Rights and Economic Development. Westview Press, Boulder

Stacey, Kiran and Williams, Aime (2021). Biden's Diplomatic Victory Blunts Pharma Lobby. Financial Times of May 10, 2021, str. 4

Steenhuis, Harm-Jan and Gray, Denis O. (2006). The University as the Engine of Growth: An Analysis of How Universities can Contribute to the Economy. Int. J. Technology Transfer and Commercialization, Vol. 5 (No. 4), str. 421-432

Stevens, Ashley J., Jensen, Jonathan J., Wyller, Katrine, Kilgore, Patrick C., Chatterjee, Sabarni and Rohrbaugh, Mark L. (2011). The Role of Public-Sector Research in the Discovery of Drugs and Vaccines. New England Journal of Medicine, Vol. 364 (No. 6), str. $535-541$

Straus, Joseph (1996). Implications of the TRIPS Agreement in the Field of Patent Law. Beier, Friedrich-Karl and Schricker, Gerhard (Eds.), From GATT to TRIPS - The Agreement 
on Trade-Related Aspects of Intellectual Property Rights (str. 160-215.), Wiley VCH, Weinheim

Straus, Joseph (1997). The Present State of the Patent System in the European Union. Office for Official Publications of the European Communities, Luxembourg

Straus, Joseph (2001). Grace Period and the European and International Patent Law, Analysis of Key Legal and Socio-Economic Aspects. IIC-Studies, Vol. 20 C.H. Beck Publishers, Munich

Straus, Joseph (2017). Research, Exploitation and Patenting in the Area of Human Embryonic Stem Cells in Europe - A Case of Concern Causing Inconsistency. European Review, Vol. 25 (No. 1), str. 107-120

Straus, Joseph (2017). Intellectual Property Rights and Bioeconomy. JIPLP, Vol. 12 (No. 7), str. 576-590

Straus, Joseph (2018). Patentierung und Kommerzialisierung im Bereich der Stammzellforschung. Zenke, Martin, Marx-Stölting, Lilian and Schickl, Hannah (Eds.), Stammzellforschung: Aktuelle wissenschaftliche und gesellschaftliche Entwicklungen. (str. 237276), Nomos, Baden-Baden

Straus, Joseph, Artificial Intelligence - Challenges and Chances for Europe (2021). European Review, Vol. 29 (No. 1), str. 142-158

Thorp, Holden H. (2020). Editorial: Science has always been Political. Science, Vol. 369 (No. 6501), str. 227

Viale, Riccardo and Etzkowitz, Henry (2005). Third Academic Revolution: Polyvalent Knowledge; The "DNA" of the Triple Helix [Digital Edition]. Preuzeto sa https://www. researchgate.net/publication/242406526_Third_academic_revolution_polyvalent_ knowledge_theDNA_of_the_triple_helix

Walsh, John P., Cohen, Wesley $\bar{M}$. and Cho, Charlene (2007). Where Excludability Matters, Material vs. Intellectual Property in Academic Biomedical Research. Research Policy, Vol. 36 (No. 8), str. 1184-2003

Walsh, John P., Baba, Yasunori, Goto, Akira and Yasaki, Yoshihito (2008). Promoting University-Industry Linkages in Japan: Faculty Responses to a Changing Policy Environment. Prometheus, Vol. 26 (No. 1), str. 39-54

Wang, Xiuqin, Xue, Lan and Shi, Dongbo (2021). Characteristics and logical framework of Chinese universities' response to the newly revised 'Bayh-Dole Act'. Studies in Science of Science [Digital Edition]. Preuzeto sa https://doi.org/10.16192/j.cnki.10032053.20201125.001 (only abstracts in English)

WIPO Technology Trends 2019 - Artificial Intelligence (2019) [Digital Edition]. Preuzeto sa https://www.wipo.int/edocs/pubdocs/en/wipo_pub_1055.pdf

Woolgar, Lee (2007). New Institutional Policies for University-Industry Links in Japan. Research Policy, Vol. 36 (No. 8), str. 1261-1274 